\title{
NOTES.
}

\section{THE DOUBLE PITCHERS OF DISCHIDIA SHELFORDII,}

sp. nov.-A previous paper contained an imperfect account, founded upon herbarium material, of the double pitchers of four species of Dischidia, viz. $D$. complex from Malacca, the Phillippine $D$. pectenoides, and two undescribed Bornean species ${ }^{1}$.

Mr. R. Shelford, M.A., Curator of the Sarawak Museum, has been so kind as to interest himself in the subject, and as a result of his endeavours complete herbarium material, as well as spirit specimens of a double-pitchered species from Kuching, have been received at Kew. These belong to a species not hitherto described, and are identical with Haviland's specimen from the Kuching Lake, bearing the number $205_{5}{ }^{2}$. Upon these specimens is founded the description of the species which I have the pleasure of naming after Mr. Shelford, who has been the first to send to me the material which rendered a knowledge of the species possible.

Dischidia Shelfordir, sp. nov. Planta epiphyta, volubilis, glabra. Folia normalia pauca, opposita, breviter petiolata, late triangularia vel suborbiculare, basi truncata, apice rotundata vel breviter apiculata, crassiuscula, arcte nervata, $\frac{1}{3}-\frac{1}{2}$ in. long. Ascidium maturum brevissime petiolatum, videtur solitarium in nodo, $\mathbf{I} \frac{1}{2}$ poll. longum, I poll. latum, $\frac{3}{4}$ poll. crassum; exterius late reniforme, colore lurido-purpureo suffusum, venis ramosis purpureis instructum (speciminibus in vini spiritu conservatis), apice invaginante introrsum et formante ascidium interius parvum. Cymae capituliformes, terminales in ramis axillaribus, 3-6florae. Flores albidi (?), pedicellis brevissimis glabris crassiusculis suffulti. Calyx alte 5-lobatus; lobi membranacei, oblongi, apice rotundati, carinati, glaberrimi, persistentes, circ. $\frac{1}{16}$ poll. longi. Corollae tubus urceolatus, quinquangularis, glaber, circ. I lin. longus ; lobi lanceolati, acuti, sub anthesin erecti, glabri, marginibus crassis,

1 Pearson, Journ. Linn. Soc. Bot., xxxv, 1902 ; pp. 375-390, with Plate IX.

${ }^{2}$ Pearson, loc. cit., 376 (and footnote), 378,379 .

[Annals of Botany, Vol. XVII. No. LXVII. June, 1903.] 
circ. $\frac{1}{2}$ lin. longi. Coronae squamae, 5, angustae, tubo stamineo affixae, membranaceae, apice alte 2 -fidea, lobis longiusculis recurvis. Antherae erectae. Stigma complanatum, obsolete 2 -lobatum, vix ex antheris exsertum. Folliculi tenues, teretes, leves, acuminati, $\mathrm{I} \frac{1}{2}-2 \frac{1}{2}$ poll. longi. Semina pilis longis albidis sericeis coronata.

Borneo: Kuching, Shelford, near Kuching Lake, Haviland 2015.

Mr. Shelford states that his specimen is epiphytic on a tree which he believes to be a species of Ficus.

\section{H. H. W. PEARSON.}

\section{STUDIES IN THE MORPHOLOGY OF SPORE.PRODUCING MEMBERS. NO. V. GENERAL COMPARISONS, AND CON.} CLUSION ${ }^{1}$.- This concluding Memoir contains a general discussion of the results acquired in the four previous parts of this series, and of their bearing on a theory of sterilization in the sporophyte. The attempt is made to build up the comparative morphology of the sporophyte from below, by the study of its simpler types; the higher and more specialized types are left out of account, except for occasional comparison. It is assumed for the purposes of the discussion that alternation of generations in the Archegoniatae was of the antithetic type, and that apogamy and apospory are abnormalities, not of primary origin.

After a brief allusion to facts of sterilization in the sporogona of Bryophytes, the similar facts are summarized for the Pteridophytes. It has been found that examples of sterilization of potentially sporegenous cells are common also in vascular plants, while occasionally cells which are normally sterile may develop spores. Hence it is concluded that spore-production in the Archegoniate plants is not in all cases strictly limited to, or defined by, preordained formative cells, or cell-groups. A discussion of the archesporium follows, and though it is found that in all Pteridophyta the sporogenous tissue is ultimately referable to the segmentation of a superficial cell, or cells, still in them, and, indeed, in vascular plants at large, the segmentations which lead up to the formation of spore-mother-cells are not comparable in all cases; in fact, that there is no general law of

1 Abstract of a paper read before the Royal Society on February 12, 1903, reprinted from the Proceedings. 


\section{$2 \mathrm{BHL}$ Biodiversity Heritage Library}

Pearson, H H W . 1903. "The double pitchers of Dischidia shelfordii, ap. nov." Annals of botany 17, 617-618.

https://doi.org/10.1093/oxfordjournals.aob.a088934.

View This Item Online: https://www.biodiversitylibrary.org/item/235015

DOI: https://doi.org/10.1093/oxfordjournals.aob.a088934

Permalink: https://www.biodiversitylibrary.org/partpdf/318732

\section{Holding Institution}

Smithsonian Libraries

\section{Sponsored by}

Biodiversity Heritage Library

\section{Copyright \& Reuse}

Copyright Status: Not in copyright. The BHL knows of no copyright restrictions on this item.

This document was created from content at the Biodiversity Heritage Library, the world's largest open access digital library for biodiversity literature and archives. Visit BHL at https://www.biodiversitylibrary.org. 